\title{
EFFECT OF WATER DEFICIT ON SNAP BEAN YIELD AND WATER USE EFFICIENCY UNDER DRIP IRRIGATION SYSTEM
}

\author{
Khedr, A. F. ${ }^{1}$ and Zedan, A. M. ${ }^{2}$
}

\section{ABSTRACT}

Field experiment was carried out at the Research Farm of Faculty of Agriculture, Suez Canal University, Ismailia, Egypt, during the summer 2016 growing season in a sandy soil with snap bean (Phaseolus vulgaris L.) under drip irrigation system. The main goal of the present work was to study effect of different emitters and water deficit $\left(T_{1}: 100 \%, T_{2}: 75 \%\right.$ and $T_{3}: 50 \%$ of evapotranspiration (ETc)) on snap bean yield and water use efficiency (WUE). Two different emitters manufactured (in-line 'Em ${ }_{1}$ ' and on-line 'Em ${ }_{2}$ ') were evaluated with lateral length $50 \mathrm{~m}$ at different operating pressures of 50,100, 150 and $200 \mathrm{kPa}$. The obtained results indicated that, the coefficient of uniformity $(C U)$ increased with increasing operating pressure from 50 to $100 \mathrm{kPa}$ and decreased with increasing operating pressure from 100 to $200 \mathrm{kPa}$. The first treatment produced high yield without significant differences of the second treatment, so, concerning the different irrigation regimes the $75 \%$ ETc treatment gave a remarkable yield and pronounced water saving equal 25 $\%$ from applied water of $T_{1}$ therefore it is technically and economically recommended and the best one for saving water. Water use efficiency was the highest in $50 \%$ ETc, but $75 \%$ ETc was the best one economically. Yield was the greatest when fresh and adequate irrigation was applied. Snap bean yield was significantly affected in a linear relationship $\left(r^{2} \geq\right.$ 0.90) by deficit irrigation conditions.

Keywords: Drip irrigation, Yield, Water use efficiency, Snap Bean.

\section{INTRODUCTION}

W ater is fast become an economically scarce resource in many areas of the world and consider as a limiting factor in any agricultural expansion depending on its quantity, quality and methods of application. In Egypt, land has been classified as arid region. Most of the Egyptian soils, out of the Nile Delta and valley, represents about $96 \%$ of the whole area, (sandy soil).

1-Lecturer of Agric. Eng., Agric. Eng. Dep., Fac. of Agric., Suez Canal Univ., Egypt. 2-Lecturer of Agric. Eng., Agric. Eng. Dep., Fac. of Agric., Zagazig Univ., Egypt. 
There are three major groups of irrigation systems: surface, sprinkler and drip (micro-irrigation). Under sandy soil condition, drip irrigation is the artificial application of water to agriculture lands in order to insure adequate for crop growth. Also, it is considered as highly efficient system because it allows small but frequent application of water with minimum losses (Locascio, 2005).

Irrigation management is a tool whereby timely application of water can improve irrigation efficiencies and ultimately yields (Baille, 1997). To improve water use efficiency (WUE), integrative measures should aim to optimize cultivar selection and agronomic practices. The relationships between crop yield and water use has been a major focus of agricultural research in arid and semi-arid regions and have been reviewed previously (Howell et al., 1998). Also water-yield relationship has been investigated using different methods of limited water applications and programs (Pandey et al., 2000).

Uniformity is an important parameter in the design and evaluating of microirrigation systems (Li et al., 2012). In Egypt, the new reclaimed areas must be use modern irrigation systems; since the traditional surface irrigation has low water use efficiency (Ragab and Prudhomme, 2002). Most of the Egyptian farmers who are living in the new reclaimed areas are small holder and facing poverty.

Snap beans (Phaseolus vulgaris L.) is one of the most important vegetable crops grown in Egypt for local market and exportation, which is rich in protein, carbohydrates, calcium $(\mathrm{Ca})$, vitamins and amino acids. The major constituents are carbohydrates $(39.7 \%)$, protein $(28.9 \%)$, fiber (22 $\%)$, fat $(0.88 \%), \mathrm{Ca}(1.8 \%)$ and phosphorus (P) $(0.13 \%)$. It is also among the most important fresh vegetables exported from developing countries and several African countries have focused on exporting snap beans to high value European markets (Ghonimy et al., 2009). So, the total cultivated area for green bean in Egypt was 46048 feddan (19347.8 hectare) in year 2000, with average of 4.3 ton/feddan, total production of 200,021 ton and the exporting crop of green bean to European markets during the summer season increased to 23000 ton in year 2000. 
Considering all other factors of production at their optimum level, crop response is defined as a crop yield decreased constantly by decreasing quantity of water applied into the root zone in deficit irrigation (Richard et al., 2002 and Amer, 2010); nevertheless, crop yield is decreased constantly by increasing quantity of water applied in surplus irrigation. The relationship between crop yield and irrigation quantity can be found from irrigation experiments in which a large range of irrigation application is conducted.

Ahmet et al. (2004) using furrow irrigation on squash found that fruit yield significantly increased in linear relationship from 22.4 to $44.7 \mathrm{Mg}$ $\mathrm{ha}^{-1}$ as irrigation water applied increased from 279 to $475 \mathrm{~mm}$ in deficit irrigation where no deep percolation occurred.

Al-Omran et al. (2005) studied squash using both surface (DI) and subsurface drip irrigation ( $S D I$ ) methods in sandy soils with three clay deposits found that fruit yield has a linear relationship to increased irrigation water level for each season within the same treatment. They found that fruit yields significantly increased with clay deposits compared with control. The differences between SDI and DI on fruit yields were also significant. Water use efficiency linearly increased as irrigation water applied increased for deficit irrigation level and decreased for excessive irrigation level.

Amer (2005) found that maximum potato yield $\left(Y_{m}\right)$ of 23.6 and 24.45 $\mathrm{Mg} \mathrm{ha}{ }^{-1}$ was achieved for 325 and $402 \mathrm{~mm}$ of optimum water use $\left(W_{m}\right)$ in winter and spring seasons, respectively. A yield reduction $\left(1-Y / Y_{m}\right)$ was linearly decreased in a rate of 0.741 by increasing water deficit fraction $\left(1-W / W_{m}\right)$ in complete deficit irrigation in range of 0.6 ET to $1.0 \mathrm{ET}$. It was constantly decreased in a rate of 0.29 by increasing deep seepage fraction in complete surplus irrigation in range of 1.0 ET to 1.4 ET. Amer (2010) working with furrow irrigated corn (Zea Mays) found that maximum yield $\left(Y_{m}\right)$ of $9.12 \mathrm{Mg} \mathrm{ha}^{-1}$ was achieved by $325 \mathrm{~mm}$ adequate irrigation quantity (d). A yield reduction $\left(1-Y / Y_{m}\right)$ was linearly decreased in a rate of 1.15 by increasing water deficit fraction $(1-\mu / d)$ in complete deficit irrigation in range of $0.6-1.0 E T_{c}$, where $Y$ is the corresponding yield achieved by irrigation quantity. He found that the crop yield was 
linearly decreased in surplus areas by increasing irrigation water quantity ranged from 1.0 to 1.4 ETC in a rate of 0.32 . Furthermore, an optimal irrigation scheduling is statistically developed based on crop response to extrapolate data from the small experiment (uniform condition) to large field (non-uniform condition) under the experiment constraints.

Enciso et al. (2007) working on onion (Allium cepa) during 2006 - 2007 fall-spring growing season with subsurface drip irrigation found that onion yield was 36.4, 39.2, $42.5 \mathrm{Mgha}^{-1}$ for 313, 353, and $393 \mathrm{~mm}$ water use (water applied plus $133 \mathrm{~mm}$ rainfall) using ET-based irrigation scheduling approach, respectively. They were 43.6, 42.2, and 34.4 $\mathrm{Mgha}^{-1}$ for 413, 363, and $323 \mathrm{~mm}$ water use using direct soil moisture monitoring based approach.

The objective of this research work was the studying the effect of different emitters and quantities of irrigation water in sandy soil on snap bean yield and water use efficiency under drip irrigation system.

\section{MATERIALS AND METHODS}

\section{Experimental setup}

Field experiment was carried out in sandy soil, at the Research Farm of Faculty of Agriculture, Suez Canal University, Ismailia, Egypt (latitude angle of $30^{\circ} 58^{\prime} \mathrm{N}$, Longitude angle of $32^{\circ} 23^{\prime} \mathrm{E}$, and elevation above sea level of $13 \mathrm{~m}$ ), Egypt, during the summer season of 2016. The setup of field experiment consists of water source from Ismailia canal (branched from Nile River), pump unit of the farm, main line with inside diameter (ID) of $\vee \cdot .6 \mathrm{~mm}$, submain line having $59.2 \mathrm{~mm}$ inside diameter, manifold lines with $44.6 \mathrm{~mm}$ branched from the submain, control valves, flow meter, pressure gauge $(0-250 \mathrm{kPa})$ with scale accuracy of $10 \mathrm{kPa}$ distributed through the submain unit to control the flow and pressure. Lateral lines made from polyethylene $(P E)$ with internal diameter $(I D)$ of $13.6 \mathrm{~mm}$ were connected with manifold line. Three irrigation treatments (irrigation with $100 \%, 75 \%$ and $50 \%$ of required water were considered as the main plots and Two different emitters were considered as sub-plots. Each sub-plot consisted of three rows each 50 meters long; rows separated from each other by $1.0 \mathrm{~cm}$ and plants spaced $50 \mathrm{~cm}$ apart in the rows. Small earth bunds and a two-meter distance between main-plots were provided to prevent water running from one main-plot to another. 
Two emitters from the local market were tested at different operating pressures of $50,100,150$ and $200 \mathrm{kPa}$ with lateral length of $50 \mathrm{~m}$. The tested emitters were divided into in-line manufactured $\left(E m_{1}\right)$ and on-line manufactured $\left(E m_{2}\right)$, emitter type with discharge $4.0 \mathrm{l} / \mathrm{h}$. The internal distance between lateral line was $100 \mathrm{~cm}$ and $50 \mathrm{~cm}$ between emitters. Irrigation water was applied at three rates based on $\left(\mathrm{T}_{1}: 100 \%, \mathrm{~T}_{2}: 75 \%\right.$ and $\left.\mathrm{T}_{3}: 50 \%\right)$ from the crop evapotranspiration $\left(E T_{c}\right)$ which calculated using CROPWAT software version 8.0 based on Penman-Monteith equation which recommended by FAO (Allen et al., 2011).

Snap bean variety (Phaseolus vulgaris $L$.) was planted on $20^{\text {th }}$ february to $20^{\text {th }}$ may 2016, the growing season lasted 90 days and chemical fertilizers were applied as following: super phosphate at rate of $150 \mathrm{~kg} / \mathrm{fed}$, ammonium sulphate at rate of $300 \mathrm{~kg} / \mathrm{fed}$ and potassium sulphate at rate of $100 \mathrm{~kg} / \mathrm{fed}$. The experiment was conducted using randomized block design (Little and Hills, 1975).

Soil and water analysis are shown in Tables (1, 2 and 3), soil properties were determined according to Black (1969). Soil mechanical analysis was carried out using the international pipette method according to Jacobs $\boldsymbol{e t}$ al. (1971). The dry bulk density of soil was determined using undisturbed soil cores according to Klute (1986). The analysis showed that at this depth the soil is considered to be homogeneous layer. The water content at field capacity $(F C)$, was measured by the method described by Tan (2005). Permanent wilting point was estimated by ROSETTA software (Shaap et al., 2001). Available water $(A W)$ was calculated based on Allen et al. (1998).

Table (1). Physical characteristics of the experimental soil.

\begin{tabular}{|c|c|c|c|c|c|c|c|c|}
\hline \multirow{2}{*}{$\begin{array}{c}\text { Soil } \\
\text { depth } \\
(\mathrm{cm})\end{array}$} & \multicolumn{3}{|c|}{$\begin{array}{c}\text { Particle size } \\
\text { distribution } \%\end{array}$} & \multirow{2}{*}{$\begin{array}{l}\text { Texture } \\
\text { Class }\end{array}$} & \multirow{2}{*}{$\begin{array}{c}D B D \\
\left(\mathrm{~g} / \mathrm{cm}^{3}\right)\end{array}$} & \multirow{2}{*}{$\begin{array}{l}F C \\
(\%)\end{array}$} & \multirow{2}{*}{$\begin{array}{c}P W P \\
(\%)\end{array}$} & \multirow{2}{*}{$\begin{array}{l}A W \\
(\%)\end{array}$} \\
\hline & Sand & Silt & Clay & & & & & \\
\hline $0-15$ & 95.47 & 2.5 & 2.03 & Sand & 1.63 & 8.6 & 1.8 & 6.8 \\
\hline $15-30$ & 98.67 & 0.3 & 1.03 & Sand & 1.67 & 8.6 & 1.8 & 6.8 \\
\hline $30-45$ & 98.60 & 0.43 & 0.97 & Sand & 1.64 & 8.6 & 2.0 & 6.6 \\
\hline $45-60$ & 98.55 & 0.93 & 0.52 & Sand & 1.68 & 8.6 & 1.8 & 6.8 \\
\hline
\end{tabular}

$F C$ : Field capacity (- $0.1 \mathrm{~atm}), P W P$ : Permanent wilting point (-15 atm),

$A W$ : Available water, $D B D$ : Dry bulk density.

Electrical conductivity $(E C)$, soil reaction $(P H)$ and soluble cations and anions (extract 1: 5) were determined according to Page (1982). 
Total calcium carbonate was determined volumetrically according to Page (1982). Sodium and potassium were determined photometrically by using flame photometer (JENWAYPEP7) according to (Richard, 1954).

Table (2): Chemical characteristics of the experimental soil.

\begin{tabular}{|c|c|c|c|c|c|c|c|c|c|c|}
\hline \multirow{2}{*}{$\begin{array}{l}\text { C.E.C } \\
\text { Mo/kg }\end{array}$} & \multirow{2}{*}{$\begin{array}{c}\text { PH } \\
1: 5\end{array}$} & \multirow{2}{*}{$\begin{array}{c}\text { EC } \\
\text { (dS/m) } \\
\text { At } \\
{ }^{\mathbf{0}} 5^{\circ} \mathbf{c}\end{array}$} & \multicolumn{4}{|c|}{$\begin{array}{c}\text { Soluble cations } \\
\text { (meq / l) }\end{array}$} & \multicolumn{4}{|c|}{$\begin{array}{c}\text { Soluble anions } \\
(\text { meq / I) }\end{array}$} \\
\hline & & & $\mathrm{Ca}^{++}$ & $\mathrm{Mq}^{++}$ & $\mathrm{Na}^{+}$ & $\mathbf{K}^{+}$ & $\mathrm{CO}^{-}$ & $\mathrm{HCO}^{-}$ & $\mathrm{Cl}^{-}$ & so ${ }^{-}$ \\
\hline 9.3 & 8.0 & 0.22 & 1.8 & 0.8 & 3.10 & 0.4 & - & 2.1 & 2.0 & 2.0 \\
\hline
\end{tabular}

Electrical conductivity $(E C)$, Water reaction $(p H)$, soluble cations and anions were determined according to Page (1982) as shown in Table (3). Table (3): Chemical characteristics of irrigation water.

\begin{tabular}{|c|c|c|c|c|c|c|c|c|c|c|}
\hline \multirow{2}{*}{ SAR } & \multirow{2}{*}{$\begin{array}{l}\text { PH } \\
1: 5\end{array}$} & \multirow{2}{*}{$\begin{array}{c}\mathrm{EC} \\
(\mathrm{d} / \mathrm{m}) \\
\mathrm{At} \\
25^{\mathbf{0}} \mathbf{c}\end{array}$} & \multicolumn{4}{|c|}{$\begin{array}{c}\begin{array}{c}\text { Soluble cations } \\
(\text { meq / l })\end{array}\end{array}$} & \multicolumn{4}{|c|}{$\begin{array}{c}\begin{array}{c}\text { Soluble anions } \\
(\text { meq / / })\end{array} \\
\text {. }\end{array}$} \\
\hline & & & $\mathrm{Ca}^{++}$ & $\mathrm{Mq}^{++}$ & $\mathrm{Na}^{+}$ & $\mathrm{K}^{+}$ & $\mathrm{CO}^{-}$ & $\mathrm{HCO}^{-}$ & $\mathrm{Cl}^{-}$ & so \\
\hline 2.66 & 8.1 & 0.48 & 1.48 & 0.79 & 2.82 & 0.25 & - & 2.91 & 0.52 & 1.91 \\
\hline
\end{tabular}

The coefficient of uniformity $(C U)$ is a better way of expressing the variation in discharge along lateral lines, it was classified as below $60 \%$, from 60 to $70 \%, 70$ to from $80 \%$, from 80 to $90 \%$; above $90 \%$ is referred to as low, poor, fair, good; excellent uniformity, respectively, and calculated using the following equation (Christiansen, 1942 and ASAE EP 458.0, 1999):

$$
C U=100\left(1-\frac{\sum_{i=1}^{i=n}\left|q_{i}-\bar{q}\right|}{n \bar{q}}\right)
$$

where, $\sum_{i=1}^{i=n}\left|q_{i}-\bar{q}\right|$ is the summation of absolute values of deviation from the means of emitter discharge, $q_{i}$ is the individual discharge of each emitter $(\ell / \mathrm{h}), \bar{q}$ is the mean of emitter discharge $(\ell / \mathrm{h})$ and $n$ is the number of collectors measured.

Irrigation water requirements of snap bean through the growing season were calculated based on the determination of crop evapotranspiration $(E T C)$ by the following equations:

$$
E T_{c}=E T_{o} \cdot k_{c}
$$




$$
I W R=E T_{c} . A . F
$$

where, $E T_{o}$ is the reference evapotranspiration ( $\mathrm{mm} /$ day), $E T_{C}$ is the crop evapotranspiration $\left(\mathrm{mm} /\right.$ day), $k_{c}$ is the crop coefficients were obtained from FAO No. 56 blication's tables (Allen et al., 1998) for stages of snap bean, $I W R$ is amounts of applied irrigation water ( $\ell /$ Irri.), $A$ is the plant area $\left(\mathrm{m}^{2}\right)$ and $F$ is the irrigation frequency.

The water application time was calculated as in the following equation (Merriam and Keller, 1978):

$$
I_{t}=\frac{I W R}{q}
$$

Where, $I_{t}$ is water application time $(\mathrm{h})$ and $q$ is the emitter discharge $(\ell / \mathrm{h})$. Three regimes (treatments) of irrigation water were applied based on the recommended crop water requirement (500 mm for snap bean) according to FAO, Doorenbos and Kassam (1986) as percentages $\mathrm{T}_{1}: 100 \% E T_{c}$ $(500 \mathrm{~mm}), \mathrm{T}_{2}: 75 \% E T_{c}(375 \mathrm{~mm})$ and $\mathrm{T}_{3}: 50 \% E T_{c}(250 \mathrm{~mm})$.

These amounts were scheduled throughout the growth season and the amounts of water that were added every irrigation and calculated according to the values of the recommended crop coefficient $\left(k_{c}\right)$ as well as the period of each stage, Doorenbos and Kassam (1986). The amounts of irrigation water were added every three days. (Table 4)

Table (4): Water applied rates throughout the growing season of snap bean in the three irrigation treatments.

\begin{tabular}{ccccccc}
\hline & & Length & \multicolumn{3}{c}{ Irrigation treatments (mm/day) } \\
Duration & Growth & $\begin{array}{c}\text { of } \\
\text { growth } \\
\text { stage }\end{array}$ & $K_{C}$ & $\left(T_{1}\right)$ & $\left(T_{2}\right)$ & $\left(T_{3}\right)$ \\
& & $\begin{array}{c}\text { stages } \\
\text { (day) }\end{array}$ & & & $75 \%$ & $50 \%$ \\
\hline $20 / 2-12 / 3$ & Initial & 20 & 0.50 & 2.82 & 2.11 & 1.41 \\
$13 / 3-11 / 4$ & $*$ Develop. & 30 & 0.75 & 5.28 & 3.96 & 2.64 \\
$12 / 4-11 / 5$ & Mid & 30 & 1.05 & 7.39 & 5.54 & 3.69 \\
$12 / 5-20 / 5$ & Late & 10 & 0.90 & 6.66 & 4.99 & 3.33 \\
\hline
\end{tabular}

*Development stage of snap bean

\section{Determination of Water Use Efficiency}

The total fresh pod weight (marketable and unmarketable yield) of the crop in each treatment was used to determine the water use efficiency 
(WUE), the WUE was calculated according to James (1988) and Bilalis et al. (2009).

$$
W U E=\frac{\text { Total weight of fresh pod }}{\text { Total water applied }}
$$

where, WUE is the water use efficience $\left(\mathrm{kg} / \mathrm{m}^{3}\right)$, total weight of fresh pod yield $(\mathrm{kg} / \mathrm{fed})$ and the total water applied $\left(\mathrm{m}^{3} / \mathrm{fed}\right)$.

\section{Crop response to water application}

Crop response between yield and water use under deficit irrigation was determined by a linear model (Doorenbos and Kassam, 19^ ; Wu and Barragan, 2000). The linear response model showed a sloped straight line in the deficit water application and a horizontal line for the crop response for surplus applications indicating no yield reduction by over irrigation. The crop response to deficit irrigation was expressed when water was uniformly applied as follows:

$$
\left(1-\frac{Y}{Y_{m}}\right)=K_{y}\left(1-\frac{W}{W_{m}}\right)
$$

Where, $Y_{m}$ and $W_{m}$ represent maximum yield and its corresponding maximum water application; $Y$ and $W$ are yield and its corresponding water application under deficit condition and $K_{y}$ is a yield reduction coefficient which is considered as a constant for a crop in deficit irrigation.

\section{RESULTS AND DISCUSSION}

\section{Discharge Uniformity}

The coefficient of uniformity $(C U)$ and the manufacturer's coefficient of variation $\left(C_{v}\right)$ as show in Table (5). The results indicated that the $C_{v}$ value classification of $E m_{1}$ emitter was excellent, due to emitter the higher quality of these emitter than $E m_{2}$ emitter. Meanwhile, $E m_{2}$ was classified as marginal, maybe due to the lowest initial price. The coefficient of uniformity $(C U)$ increased with increasing operating pressure from 50 to $100 \mathrm{kPa}$ and decreased with increasing operating pressure from 100 to $200 \mathrm{kPa}$ as shown in Figure (1). 
Table (5): The coefficient of uniformity and manufacturing coefficient of variation $\left(C_{v}\right)$ for emitters.

\begin{tabular}{lcccccc}
\hline & \multicolumn{2}{c}{ Coefficient of uniformity $(\mathrm{CU}, \%)$} & \multicolumn{2}{c}{$" C_{v}{ }^{\prime}$} \\
Emitter & \multicolumn{3}{c}{ operating pressure $(\mathrm{kPa})$} & & Value & Classi. $^{*}$ \\
& 50 & 100 & 150 & 200 & & \\
\hline$E m_{1}$ & 94.35 & 96.78 & 93.62 & 90.82 & 0.02 & Excellent \\
$E m_{2}$ & 75.31 & 84.01 & 79.81 & 75.25 & 0.10 & Marginal \\
\hline
\end{tabular}

"Classification of the emitter manufacturing coefficient of variation.

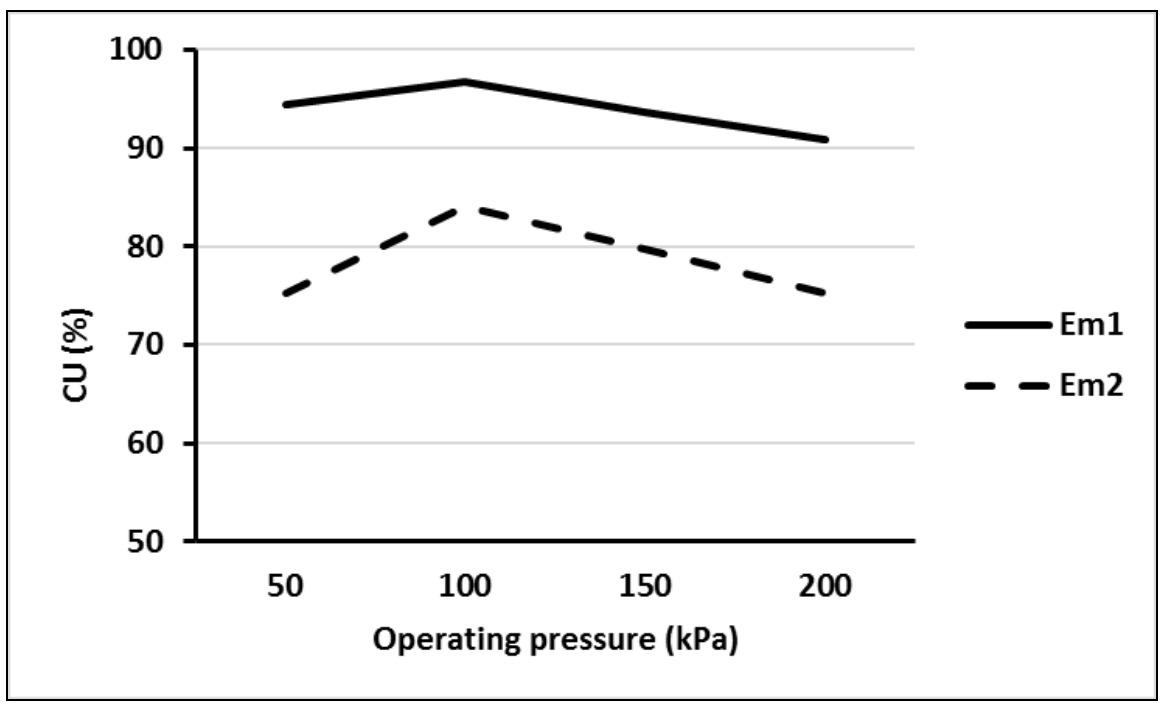

Figure (1): The relationship between operating pressure and coefficient of uniformity.

\section{Yield and water application rate:}

The effect of water application rate on snap bean yield under the drip irrigation system during the growing season was shown in Figures ( 2 and $3)$. It is evident that the maximum yield of snap bean is obtained in the treatment of $T_{1}$ for $E m_{1}$ emitter, while the lower yield is recorded in $T_{3}$ for $E m_{2}$ emitter due to the $E m_{1}$ high coefficient of uniformity $(C U)$. Generally, high yield was achieved may be due to high soil fertility (reclaimed sandy soil) caused by addition of the organic and inorganic fertilizers. The variation between the three water treatments is due to the distinctness of applied water quantities. Yield of the first and second treatments did not expose to soil water stress because of the irrigation 
water quantity, which was applied for irrigating the snap bean which covered its water requirements.

Figures (2 and 3) shows that the depths of water application in $T_{1}$ is (2088.10 $\left.\mathrm{m}^{3} / \mathrm{Fed}\right),\left(1565.23 \mathrm{~m}^{3} / \mathrm{Fed}\right)$ for $\mathrm{T}_{2}$ and $\left(1038.9 \mathrm{~m}^{3} / \mathrm{Fed}\right)$ for $\mathrm{T}_{3}$, while the average yields are $(4400.26 \& 4000.81 \mathrm{~kg} / \mathrm{Fed}),(4098.26 \&$ $3710.30 \mathrm{~kg} / \mathrm{Fed})$ and $(2964.39 \& 2610.12 \mathrm{~kg} / \mathrm{Fed})$ of $E m_{1}$ and $E m_{2}$ emitter for $T_{1}, T_{2}$ and $T_{3}$, respectively. The yield increments may be attributed to the increase of leaves number per plant in $\left(T_{1}\right.$ and $\left.T_{2}\right)$ which developed photosynthesis process. This leads to improve fruit number per plant in these treatments. On contrary, lower yield under $T_{3}$ may be due to the small fruits of plant did not complete their life cycle. Also, snap bean plant is classified drought sensitive crops, and so plants suffer from water stress. This finding is in agreement with Raj Kumar and Kamia (1985). There is no difference between yield of $T_{1}$ and $T_{2}$, while there are significant differences between $\mathrm{T} 3$ and $\mathrm{T}_{1}$ and $\mathrm{T}_{2}$. Results indicated, in general, that, $\mathrm{T}_{2}$ saved about $522.874 \mathrm{~m}^{3} /$ fed which equal $25 \%$ from applied water of $T_{1}$. So, $T_{2}$ is the best water treatment in water saving and good yield since there is no any significant difference with $\mathrm{T}_{1}$ especially when yield was considered.

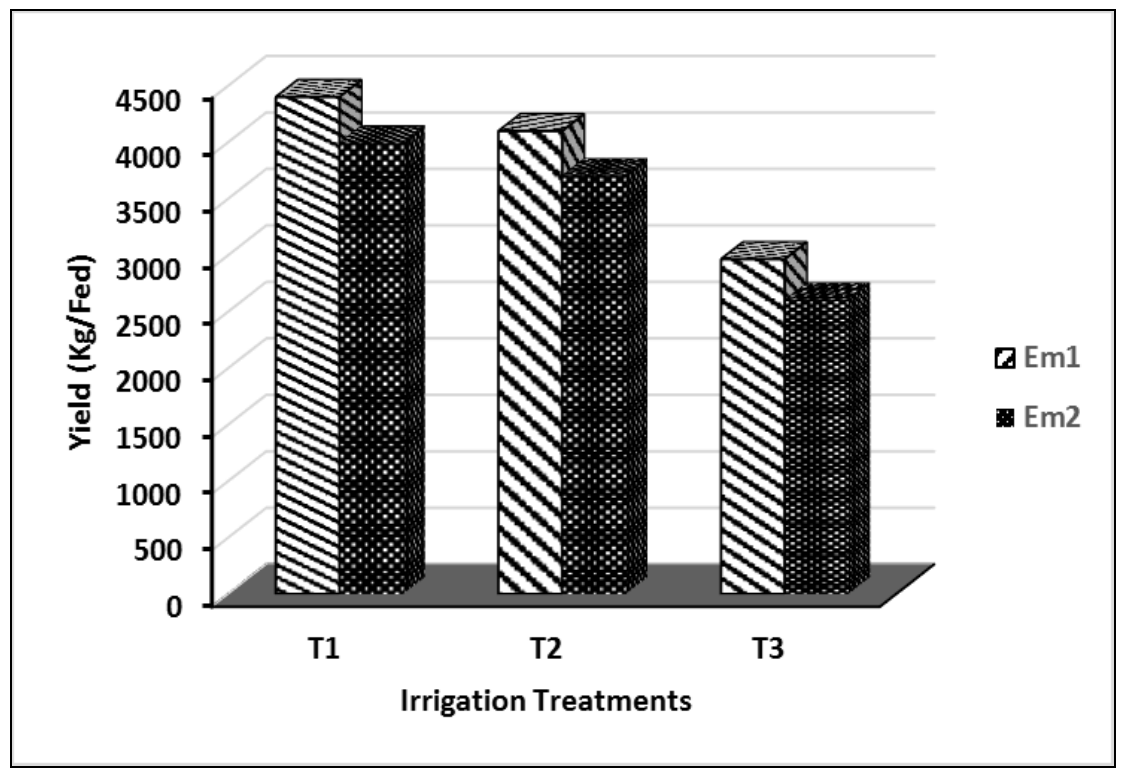

Figure (2): Effect of water application rate on snap bean yield. 


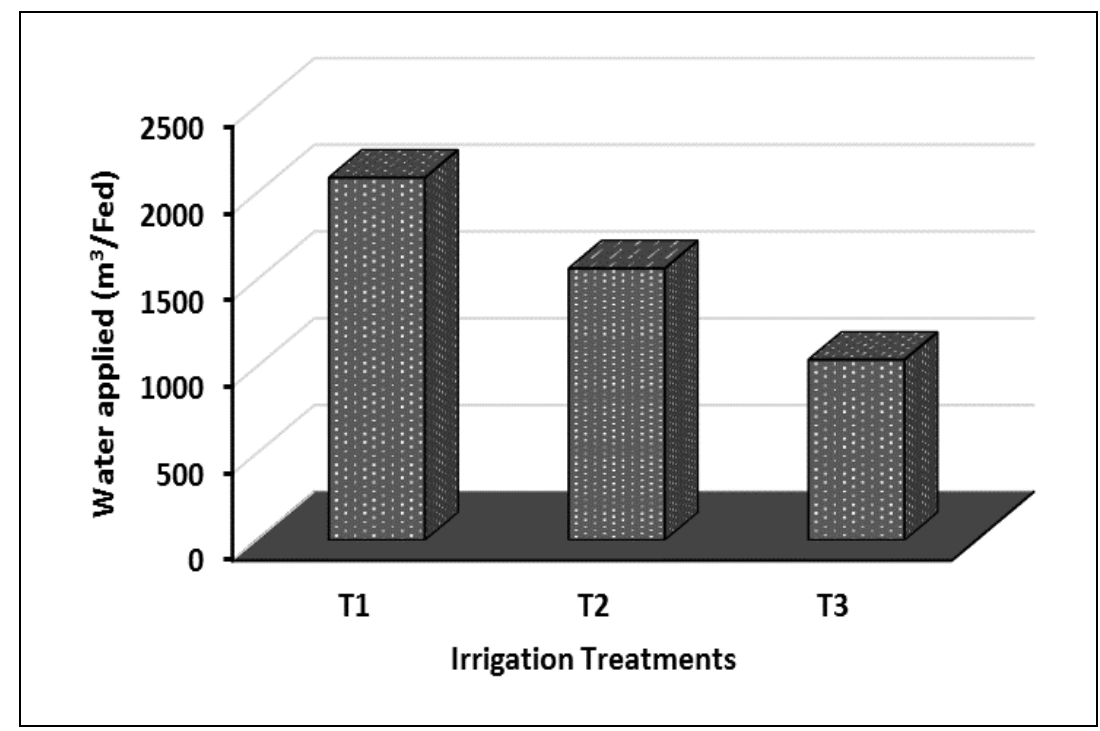

Figure (3): Water application rate by the three irrigation treatments.

\section{Water use efficiency (WUE)}

The uniformity plays an important role in water use efficiency (WUE). Water use efficiency is the ratio between crop yield and total amount of water, and expresses as $\mathrm{kg}$ of yield per $\mathrm{m}^{3}$ of used water. Data illustrated by (Figure 4) clarified the effect of water application rate on water use efficiency. The efficient use of applied water was graphically illustrated by Figure (4). The output of water use efficiency for irrigating Snap Bean plant under drip irrigation system three water treatments was calculated using WUE formula. This formula often uses to know the importance of plant yield relative to irrigation water in a certain area. WUE was 2.107, 2.618 and $2.853 \mathrm{~kg} / \mathrm{m}^{3}$ of $E m_{1}$ and $1.916,2.37$ and $2.512 \mathrm{~kg} / \mathrm{m}^{3}$ of $E m_{2}$ for $T_{1}, T_{2}$ and $T_{3}$ treatments, respectively. In general, it could be noticed that the yield decreases with decreasing the water application rate. It is clear from the obtained results that the highest value of WUE was achieved at $E m_{1}$ emitter, which could be recommended for drip irrigated Snap Bean in sandy soil. The high yield is induced at $\mathrm{T}_{1}$ for $E m_{1}$ emitter. The values of water use efficiency (WUE) are decreased with increasing the amount of irrigation water added, except under the treatment of $\mathrm{T}_{3}$ due to the lowest obtained yield in this treatment. These results are in 
agreement with Lin et al. (1983) who reported that, the values of WUE were increased with decreasing the amount of irrigation water added.

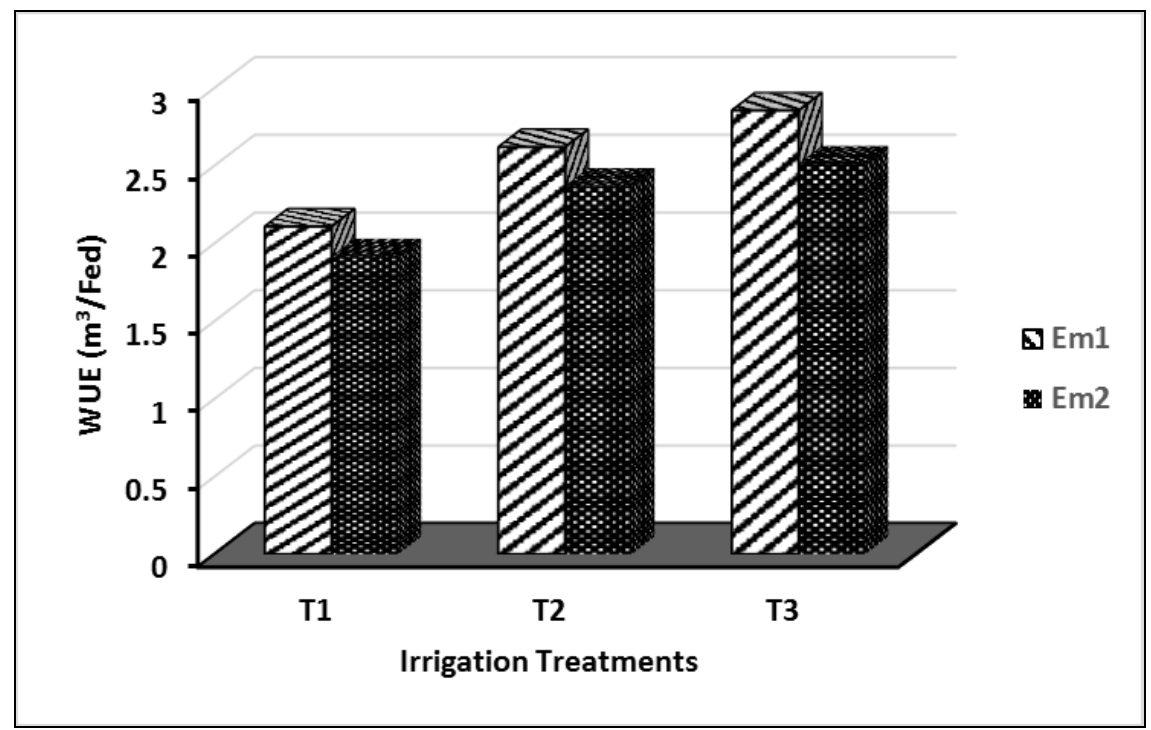

Figure (4): Effect of water application rate on water use efficiency.

The highest $W U E$ value was recorded with $\mathrm{T}_{3}$ followed by $\mathrm{T}_{2}$ and then $\mathrm{T}_{1}$ treatment. Snap bean yield for $\mathrm{T}_{3}$ represents $67 \%$ from yield of $\mathrm{T}_{1}$, whenever yield of $\mathrm{T}_{2}$ was $93 \%$ from yield of $\mathrm{T}_{1}$. This increment in yield (93 - $67=26 \%$ ) between $\mathrm{T}_{2}$ and $\mathrm{T}_{3}$ was due to increasing irrigation water with $25 \%$ from used water in $\mathrm{T}_{1}$, so yield of $\mathrm{T}_{2}$ represents the economic yield because of increasing water $25 \%$ gives also the same ratio from yield approximately $(26 \%)$. So, $\mathrm{T}_{2}$ is considered the best treatment between the three treatments under study. $\mathrm{T}_{3}$ is considered the best treatment under rainy areas because of rarely water (irrigation water shortage). Generally, WUE for snap bean yield decreases with increasing irrigation water applied.

\section{Snap bean response}

Snap bean was affected by irrigation regime with used both two emitters $E m_{1}$ and $E m_{2}$ (Figure 5). Maximum yields $\left(\mathrm{Y}_{\mathrm{m}}\right)$ for $100 \% E T_{c}$ were 4.4 and $4.0 \mathrm{Mg}$ /fed for $E m_{1}$ and $E m_{2}$ respectively. Yield for $\mathrm{T}_{2}\left(75 \% E T_{c}\right)$ was 4.09 and $3.71 \mathrm{Mg} /$ fed and minimum yield obtained by $\mathrm{T}_{3}\left(50 \% E T_{c}\right)$ was 2.96 and $2.61 \mathrm{Mg} / \mathrm{fed}$ for $E m_{1}$ and $E m_{2}$, respectively. A no significant 
difference was found between snap bean yield obtained by both $T_{1}$ and $T_{2}$ treatments with $E m_{1}$ and $E m_{2}$. Snap bean yield significantly decreased in linear relationship with increasing water deficit. However, it was not significantly changed by water applied above $75 \%$ ETc. the highest yields were achieved with the $100 \%$ ETc treatment, similar results were obtained by Mao et al. (2003) on cucumber and Saleh and Ibrahim (2007) on cantaloupe.

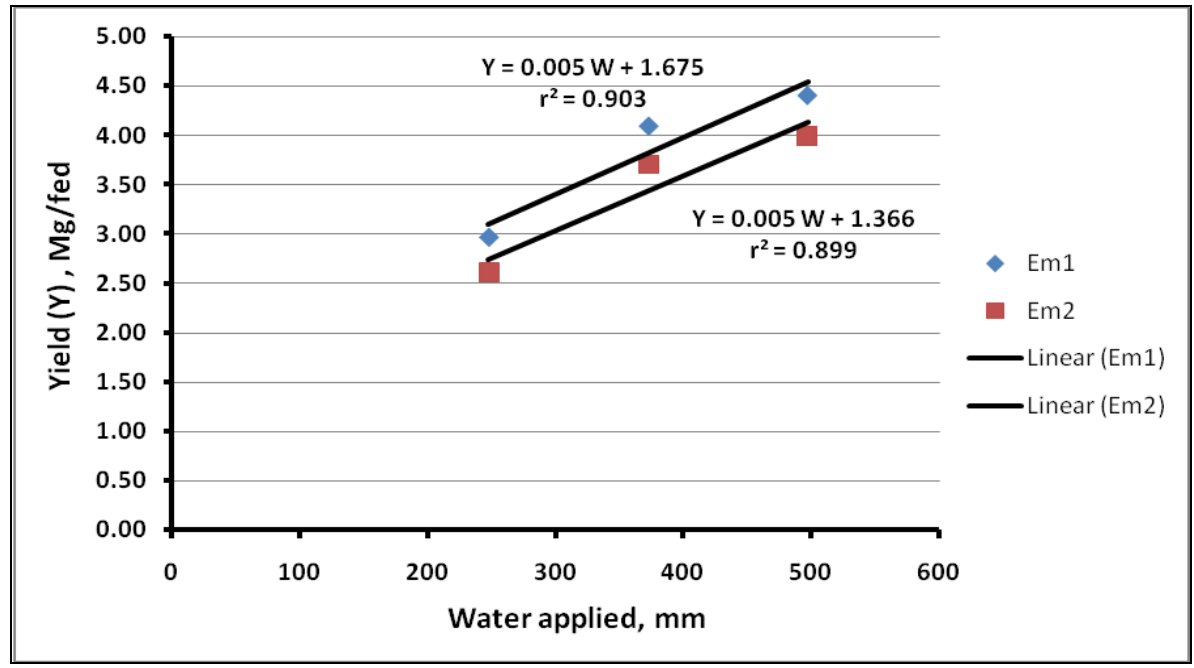

Figure (5): Snap bean yield versus water applied under different irrigation levels.

The results showed that snap bean yield increased linearly with increasing irrigation water application up to $497.2 \mathrm{~mm}$ where maximum yield was $4.4 \mathrm{Mg} / \mathrm{fed}$. When water applied was reduced to $372.7 \mathrm{~mm}$, the yield decreased to $4.09 \mathrm{Mg} / \mathrm{fed}$. Therefore, the yield reduction coefficient was recorded as 0.28 , and found that water irrigation greater than $497.2 \mathrm{~mm}$ resulted in no significant increase in yield.

The result founded that a linear relationship for whole growth period as $Y=0.005 W+1.675$ with $r^{2}=0.903$ for $E_{1}$; $Y=0.005 \mathrm{~W}+1.366$ with $r^{2}=0.899$ for $E m_{2}$, where, $Y$ is in $\mathrm{Mg} / \mathrm{fed}$ and $W$ is in $\mathrm{mm}$. the snap bean maximum yield was 4.4 and $4.0 \mathrm{Mg} / \mathrm{fed}$ for $497.2 \mathrm{~mm}$ optimum water use with $E m_{1}$ and $E m_{2}$ respectively. The yield reduction coefficient $\left(K_{y}\right)$ was determined as 0.28 and 0.32 for $E m_{l}$ and 
$E m_{2}$, respectively by applying deficit irrigation $T_{2}$ (75\% treatments), on the other hand when applying $T_{3}(50 \%)$ the yield reduction coefficient $\left(K_{y}\right)$ was determined as 0.66 and 0.70 for $E m_{1}$ and $E m_{2}$, respectively, so $T_{2}$ recommended for saving water with minimum yield reduction coefficient.

Expressing yield and application of water or ET in relative terms by dividing yield $\left(Y_{a}\right)$ by maximum yield $\left(Y_{m}\right)$ and Eta by $E T_{m}$ and subtracting from results in a relative deficit water production function:

The yield reduction coefficients $\mathrm{Ky}_{1}$ and $\mathrm{Ky}_{2}$ were, respectively, considered as $\mathrm{k}_{1}$ and $\mathrm{k}_{2}$ in deficit irrigation conditions as:

$$
\begin{array}{ll}
\left(1-\frac{Y_{a}}{Y_{m}}\right)=0.28\left(1-\frac{E T_{a}}{E T_{m}}\right) \quad \text { For } T_{2} \text { with } E m_{1} \\
\left(1-\frac{Y_{a}}{Y_{m}}\right)=0.32\left(1-\frac{E T_{a}}{E T_{m}}\right) \quad \text { For } T_{2} \text { with } E m_{2} \\
\left(1-\frac{Y_{a}}{Y_{m}}\right)=0.66\left(1-\frac{E T_{a}}{E T_{m}}\right) \quad \text { For } T_{3} \text { with } E m_{1} \\
\left(1-\frac{Y_{a}}{Y_{m}}\right)=0.70\left(1-\frac{E T_{a}}{E T_{m}}\right) \quad \text { For } \mathrm{T}_{3} \text { with } E m_{2}
\end{array}
$$

The coefficient of $0.28,0.32,0.66$ and 0.70 are a crop deficit coefficient and relates the relative reduction in yield to the relative in $E T$.

Snap bean yield was decreased by decreasing water applied due to water deficit into root zone. It was decreased by increasing irrigation water amount in surplus irrigation due to over wetting stress on plant roots and causing more weed and insect problems, even those were controlled; also, Snap bean plants are also very sensitive to excessive water and tended to produce more vegetative growth and lessening grain yield. Other problem which is leaching some fertilizers from root zone by deep seepage could be the reason if additional fertilizers were not added. A relative yield $\left(Y_{a} / Y_{m}\right)$ was found as a linear relationship with uniform water applied ratio $\left(E T_{a} / E T_{m}\right)$ in deficit irrigation conditions as shown in Figure 6. 


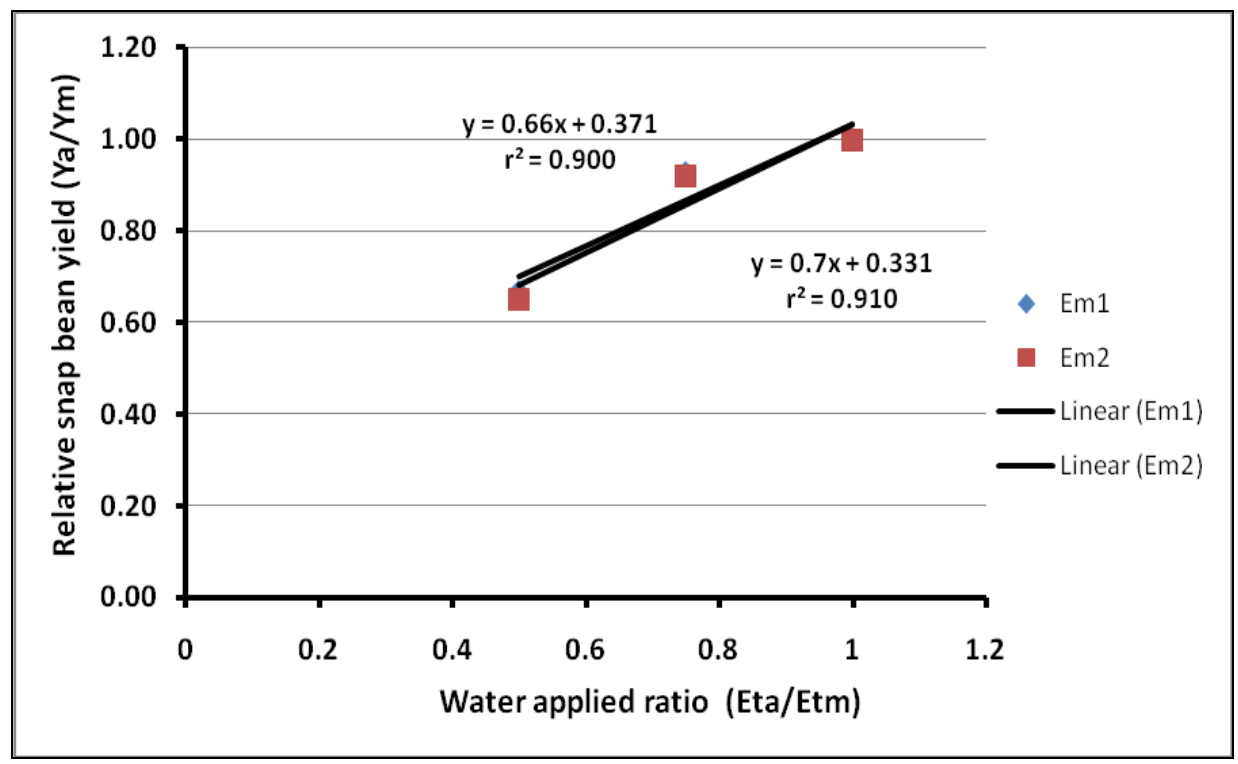

Figure (6): Relative snap bean yield versus water applied ratio under different irrigation levels.

Snap bean yield related to its corresponding uniform irrigation water applied depth was found under trickle irrigation method as shown in Figure 5. It decreased as water applied decreased in deficit irrigation due to plant stress causing by drier soil. The same results were also obtained by Diaz-Perez et $\boldsymbol{a l}$. (2004) working on pepper and Wan $\boldsymbol{e t}$ al. (2010) working on cucumber, both of them found that yield was negatively affected by excessive irrigation. For an adequate irrigation quantity $\left(100 \% E T_{c}\right.$ ), maximum yield values were 4.4 and $4.0 \mathrm{Mg}$.fed $^{-1}$ for $T$, and 4.09, $3.71 \mathrm{Mg} . f e d^{-1}$ for $T_{2}$ under trickle irrigation method with $E m_{1}$ and $E m_{2}$, respectively. However, yield reduction $\left(1-Y_{a} / Y_{m}\right)$ was found in a linear relationship with uniform water applied fraction in small experiment plots in either deficit irrigation conditions $\left(1-\mathrm{Et}_{\mathrm{a}} / \mathrm{Et}_{\mathrm{m}}\right)$ as shown in Figure 7. Snap bean yield reduction coefficients using regression as shown in Figure 7 were, respectively, found as $0.28\left(K y_{1}\right.$ with $\left.\mathrm{r}^{2}=0.91\right)$ and $0.32\left(K y_{2}\right.$ with $\left.\mathrm{r}^{2}=0.90\right)$ in deficit irrigation conditions for emitters $E m_{l}$ and $E m_{2}$, respectively. 


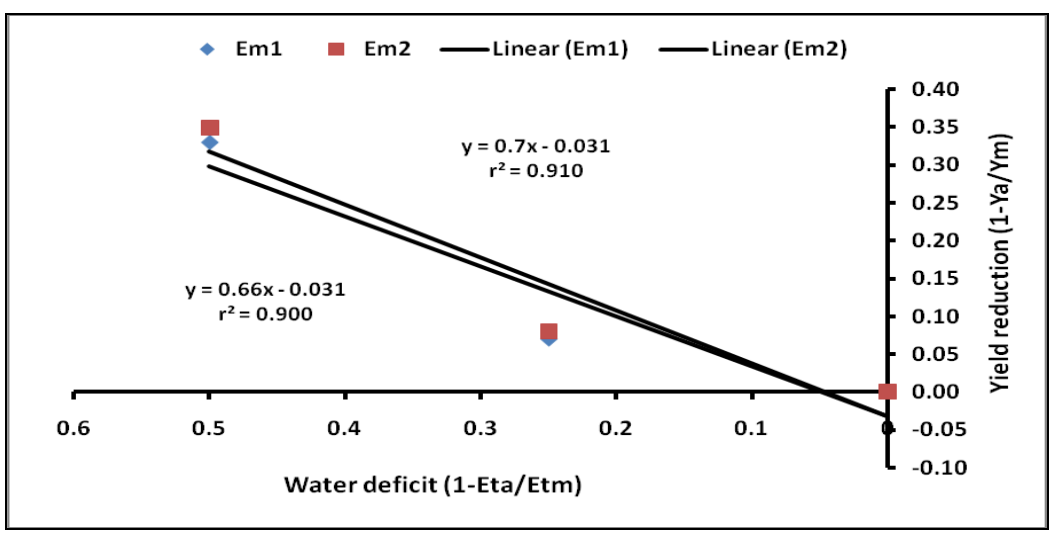

Figure (7): Relationship between snap bean yield reduction and water deficit

\section{Distribution pattern of emitters}

The soil moisture pattern content before and after irrigation for emitters $E m_{1}$ and $E m_{2}$ at water deficit $\left(\mathrm{T}_{1}: 100 \%, \mathrm{~T}_{2}: 75 \%\right.$ and $\left.\mathrm{T}_{3}: 50 \% E T c\right)$ as shown in (Figure 8 ). The results of emitters showed that before irrigation the soil moisture content decreased by increasing the depth for all treatments, except at depth of $30 \mathrm{~cm}$ at $0-12.5 \mathrm{~cm}$ horizontally from emitter. The soil available water $(A W)$ of the snap beans was $6.80 \%$ where the radial available water $(R A W)$ equal $4.50 \%$, so that, the crop was not exhausted. It is well known that after irrigation directly the soil moisture content increases in all layers of the soil depth and filled completely. The results showed that the soil moisture content after irrigation with increased at the depth of $0-30 \mathrm{~cm}$ reaching value of $8.2 \%$ and decreased up till $3.44 \%$ at a depth of $45-60 \mathrm{~cm}$ when the distance from emitters was 0-12.5 cm at water deficit $\left(\mathrm{T}_{1}: 100 \%\right.$ ETc) of emitter $E m_{1}$. However, water deficit $\left(\mathrm{T}_{3}: 50 \% E T c\right)$ decreased the soil moisture content from $8.2 \%$ to $5.2 \%$ at the same depth, respectively. Generally, for all emitters the soil moisture distribution pattern value was inversely proportional with the depth and the horizontal distance from emitter. The best soil moisture distribution pattern was noticed at $E m_{l}$ emitter at water deficit $\left(\mathrm{T}_{1}: 100 \%\right.$ ETc) due to an increase in the time of irrigation and low flow rate. These results showed that the soil moisture distribution pattern were between field capacity $(F C)$ and permanent wilting point $(P W P)$ or may be at radial available water $(R A W)$ for all different emitters at different treatments. 


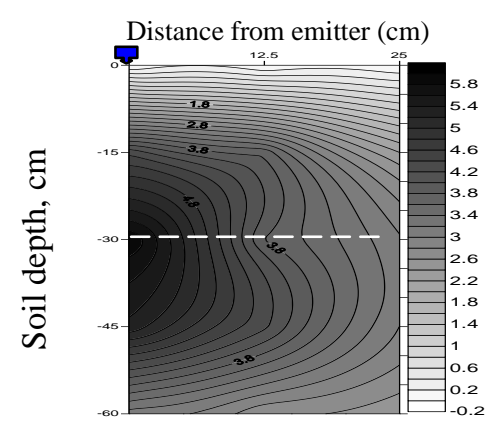

$\mathrm{T}_{1}$

Before irrigation of $E m_{l}$

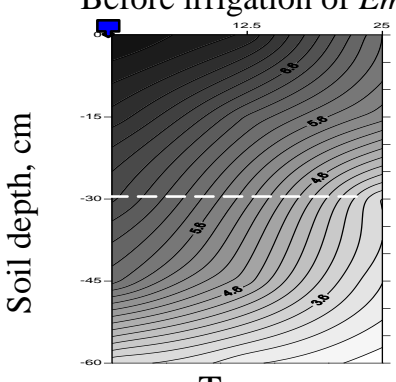

$\mathrm{T}_{1}$

After irrigation of Em

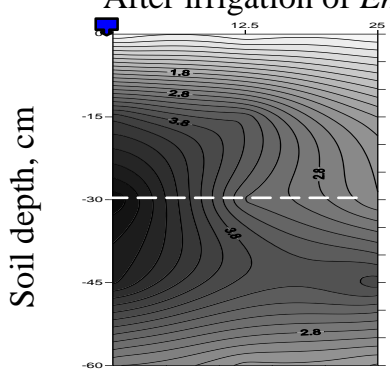

$\mathrm{T}_{1}$

Before irrigation of $\mathrm{Em}_{2}$

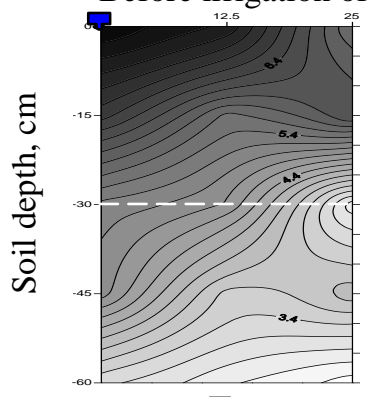

$\mathrm{T}_{1}$

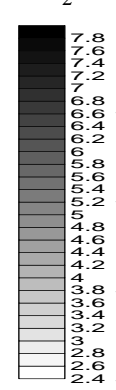

$-8$

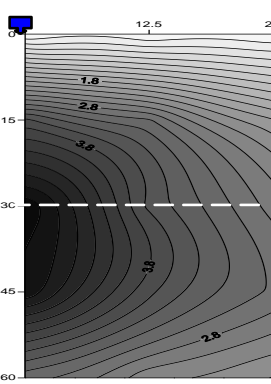

$\mathrm{T}_{2}$

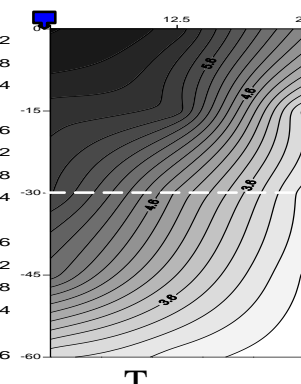

$\mathrm{T}_{2}$

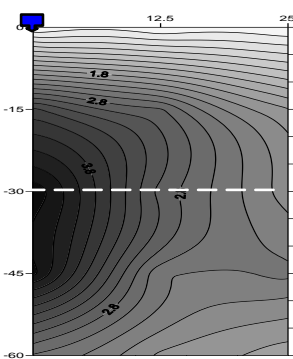

$\mathrm{T}_{2}$

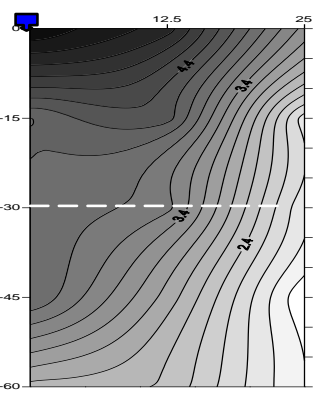

$\mathrm{T}_{2}$

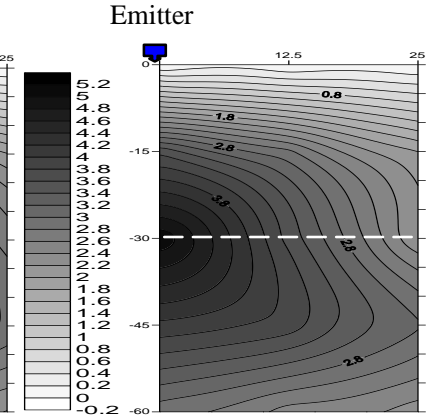

$\mathrm{T}_{3}$
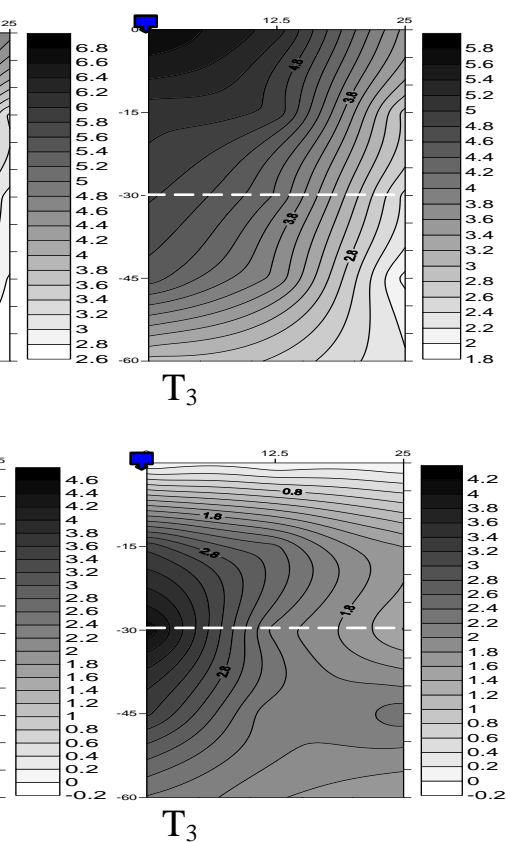

$\mathrm{T}_{3}$

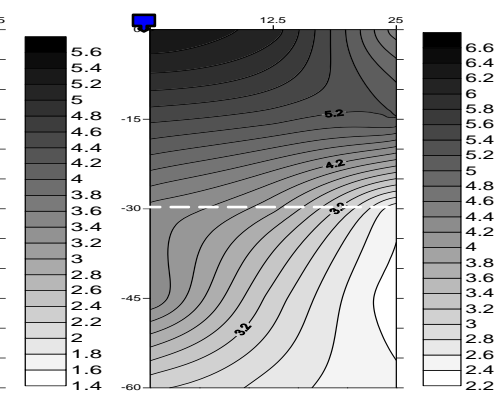

$\mathrm{T}_{3}$

After irrigation of $\mathrm{Em}_{2}$

Figure (8): Average season stage of snap beans soil moisture distribution pattern of emitters $\left(E m_{1}\right.$ and $\left.E m_{2}\right)$ before and after irrigation at different treatments $\left(T_{1}, T_{2}\right.$ and $\left.T_{3}\right)$ 


\section{CONCLUSION}

In this present research work, several conclusions can be obtained and drawn as follows:

1- Generally, the highest value of $C U$, yield and $W U E$ was achieved at $E m_{1}$ emitter.

2- High yield was recorded in $\mathrm{T}_{1}$ treatment, on the other hand, there was no significant differences between $\mathrm{T}_{1}$ and $\mathrm{T}_{2}$, therefore $75 \%$ $E T_{c}$ treatment saved about $25 \%$ from applied water of the first treatment, so, it is the best water treatment for water saving and considerable yield.

3- Water use efficiency was the highest in $50 \% E T_{c}$, but $75 \% E T_{c}$ was the best one economically.

4- Snap bean yield was significantly affected in a linear relationship $\left(r^{2} \geq 0.90\right)$ by deficit irrigation conditions.

5- The best treatment for saving water was $75 \% E T_{c}$ and giving optimum yield of snap bean under sandy soil.

\section{REFERENCES}

Ahmet, E.; S. Sensoy; C. Kucukyumuk and I. Gedik (2004). Irrigation frequency and quantity affect yield components of spring squash (Cucurbita pepo L.). Agric. Water Manage. 67, 63 - 76.

Allen, R. G.; L. S. Pereira; D. Raes and M. Smith (1998). Crop Evapotranspiration Guidelines for Computing Crop Water Requirements. FAO Irrigation. and Drain. Paper 56. United Nations, Rome, Italy, pp. 30 - 42.

Allen, R. G.; L. S. Pereira; R. Dirk and M. Smith (2011). Crop Evapotranspiration Guidelines for computing crop water requirements. FAO Irrigation and Drainage Paper No. 56, 1998. Food and Agriculture Organization. Rome, Italy, pp. 83.

Al-Omran, A. M.; A. S. Shetaa; A. M. Falataha and A. R. Al-Harbi (2005). Effect of drip irrigation on squash (Cucurbita pepo) yield and water-use efficiency in sandy calcareous soils amended with clay deposits. Agric. Water Manage., 73, 43 - 55. 
Amer, K. H. (2005). Trickle irrigation evaluation and schedules. Egyptian J. Ag. Eng., 22 (3): 899 - 922.

Amer, K. H. (2010). Corn crop response under managing different irrigation and salinity levels. Agric. Water Manage., (97), 1553 1663.

ASAE EP 458.0 (1999). Field evaluation of microirrigation systems. ASAE December 1999. ASAE. 792 - 797.

Baille A. (1997). Principles and methods for predicting crop water requirement in greenhouse environments. CIHEAM, Cahiers Options Mediterranéennes, 31: 177 - 187.

Bilalis, D.; A. Karkanis; A. Efthimiadou; Ar. Konstantas and V. Triantafyllidis (2009). Effects of irrigation system and green manure on yield and nicotine content of Virginia (flue-cured) Organic tobacco (Nicotiana tabaccum), under Mediterranean conditions. Industrial Crops and Products, 29(2-3): 388 - 394.

Black, C. A. (1969). Methods of soil analysis. American Society of Agronomy. Inc., Publisher Madison, Wisconsin, USA.

Christiansen, J. E. (1942). Irrigation by sprinkler. Bulletin 670 . California Agricultural Experiment Station. University of California. Berkeley, USA, pp. 124.

Diaz-Perez, J. C.; D. Granberry; K. Seebold; D. Giddings and D. Bertrand (2004). Irrigation levels affect plant growth and fruit yield of drip-irrigated bell pepper. HortScience, 39 (4): 748 - 749.

Doorenbos, J. and A. H. Kassam. (1986). Yield response to water. Irrigation and drainage. Paper No 33. Rome, Italy: FAO.

Enciso, J.; J. Morales; B. Wiedenfeld; S. Nelson and X. Peries (2007). Irrigating onions with subsurface drip irrigation under different stress levels. December 9 - 11. $28^{\text {th }}$ International Irrigation Conf. Irrigation Association, San Diego, pp. 338 - 352.

Ghonimy, M. I.; A. E. E. Suliman; W. M. Ibrahim and E. N. Abd El Rahman (2009). Design of snap bean pods harvesting prototype 
by stripping. In proceeding paper, $4^{\text {th }}$ Conference on Recent Technologies in Agriculture. Cairo University, Egypt.

Howell, T. A.; J. A. Tolk; D. S. Arland and R. Evertt (1998). Evapotranspiration, yield and water use efficiency of corn hybrids differing in maturity. Agron. J., 90: 3 - 9.

Jacobs, H. S.; R. M. Reed; S. J. Thien and Withee (1971). Soils laboratory exercise source book. Am. Soc of Agron. Mandison, Wisconsin.

James, L. G. (1988). Principles of farm irrigation system design. New York: John Wiley and Sons. pp. 545.

Klute, A. (1986). Methods of soil analysis. Part 1. Physical and mineralogical methods ( $2^{\text {nd }}$ edition). American Society of Agronomy Inc., Madison, Wisconsin, USA.

Li, J.; W. Zhao; J. Yin; H. Zhang; Y. Li and J. Wen (2012). The effects of drip irrigation system uniformity on soil water and nitrogen distributions. Trans. of the ASABE, 55(2): 415 - 427.

Lin, S. S. M.; J. N. Hubbel and C. S. Tsou Samson (1983). Drip irrigation and tomato yield under tropical conditions. HortScience 18(4): pp. 460 - 461.

Little, T. M. and F. J. Hills (1975). Statistical methods in agricultural research. UCD Boostore, Davis, California.

Locascio, J. S. (2005). Management of irrigation for vegetables: past, present, future, Hort technology, 15(3): 482 - 485.

Mao, X.; M. Liu; X. Wang; C. Liu; Z. Hou and J. Shi. (2003). Effects of deficit irrigation on yield and water use of greenhouse growth cucumber in the North China Plain. Agric. Water Manage. 61: 219 -228 .

Merriam, J. L. and J. Keller (1978). Farm Irrigation System Evaluation: A Guide for Management $3^{\text {rd }}$ ed. Logan, Utah: Agricultural and Irrigation Engineering Department, Utah State University, pp. 271. 
Page, A. L. (1982). Methods of soil analysis, part II. Chemical and microbiological properties. Am. Soc. Agron., Inc. Soil Sci. Soc. Am. Inc. Madison, Wisconsin, USA.

Pandey, R. K., J. W. Maranvilla and M. M. Chetima (2000). Deficit irrigation and nitrogen effects on maize in a Sahelian environment. Part II. Shoot-growth, nitrogen uptake and water extraction. Agric. Water Manage., 46: 15 - 27.

Ragab, R. and C. Prudhomme (2002). Climate change and water resources management in arid and semi-arid regions-prospective and challenges for the $21^{\text {st }}$ century. Biosystms Eng., 81(1): 3 - 34 .

Raj Kumar, S. and Kamia L. (1985). Movement of salt and water under trickle irrigation and its field evaluation. Egypt J. Soil Sci., 2: 127 -132 .

Richard, L. A. (1954). Diagnosis and Improvement of Saline and Alkaline Soils, U.S.S.L. Staff Agric. Hand book No. 60.

Richard, M.; A. Jose; G. Mark and M. Keith (2002). Spring Squash Production in California. Vegetable Research and Information Center, Vegetable Reproduction Series, California, Publication 7245 .

Saleh, M. M. and M. A. Ibrahim (2007). Effect of different irrigation levels on production, quality, and storg eability of cantaloupe (Cucumis melo L.) grown under polyethylene low tunnels in a newly reclaimed land. Egyptian J. Agric. Res., 32(4):1109 - 1124.

Tan, K. H. (2005). Soil Sampling, Preparation and Analysis. Taylor \& Francis Group. London.

Wan, S.; Y. Kang; D. Wang and S. Liu (2010). Effect of saline water on cucumber (Cucumis sativus L.) yield and water use under drip irrigation in North China. Agric. Water Manage., (98), 105 - 113.

Wu, I. P. and J. Barragan (2000). Design criteria for microirrigation systems. Trans. ASAE 43 (5), 1145 - 2115. 
Shaap, M. G.; F. J. Leij and M. T. van Genuchten (2001). ROSETTA: a computer program fir estimating soil hydraulic parameters with hierarchical pedotransfer function. J. Hydrol., 251: 163 - 173.

\section{الملخص العربي}

تأثير العجز المائى على إنتاجية الفاصوليا

وكفاءة استخدام المياه تحت نظام الرئ الرى بالتنقيط

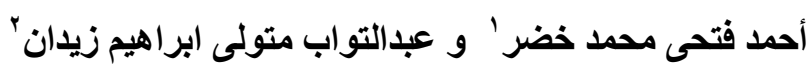

أجري تجربة حقلية بمزرعة كلية الزراعة - جامعة قناة السويس، بالإسماعيلية، مصر خلال

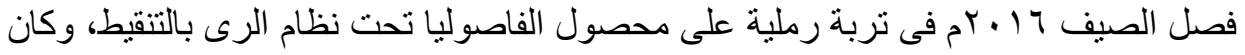

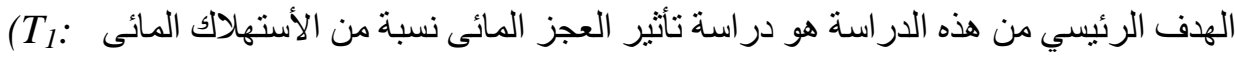
100\%, T2: 75 \% and T3: 50 \% ETC)

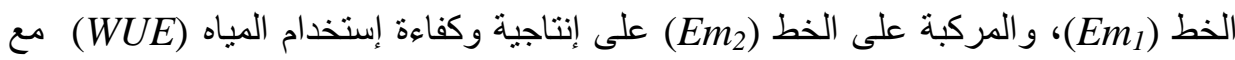

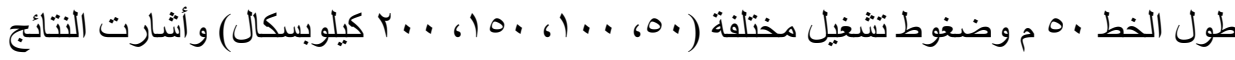

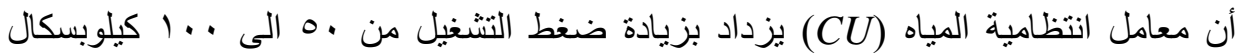

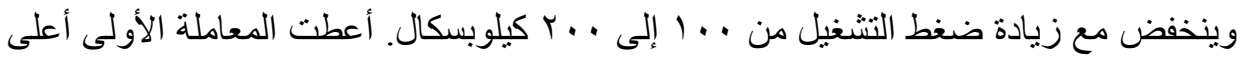

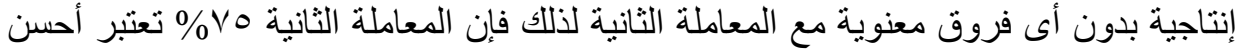

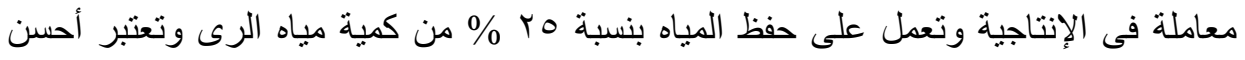

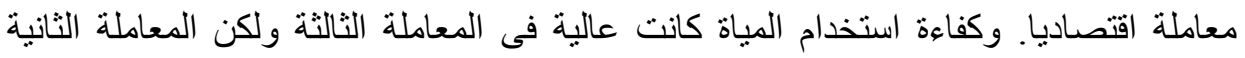

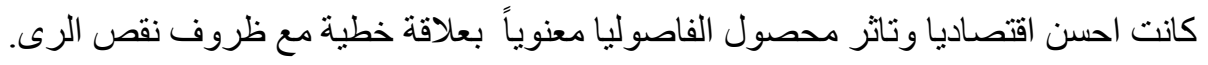

